\title{
The Dynamics of Actor Addiction Issues in the Design of Insurance Governance of Indonesian Labor
}

\author{
Anita Kristina* \\ Khusnul Ashar \\ Iswan Noor \\ Susilo \\ Doctoral Program of Economics, Faculty of Economic and Bussiness, \\ Universitas Brawijaya,Jl. MT. Haryono 165 Malang 65145, Indonesia \\ ${ }^{*}$ Corresponding Author
}

Doi:10.5901/mjss.2017.v8n2p37

\begin{abstract}
This study delivers an overview of the actor interaction process in the insurance management design of Indonesian Labor. The discussion began from exploring the governance mechanism systems in the perspective of institutional design with many dynamic issues. Next, discussing how the actors interact to the same destination and how other players face their dependence on powerful actors. Insurance governance design of Indonesian labor shows the need for management changes, which tends to form a pattern of unequal power structures. Core actors in the management relationship construct a dependency relationship, as a result of unbalanced information and profile load of insane decision-making.
\end{abstract}

Keywords: governance mechanism, institutional actor dependence, institutional design

\section{Introduction}

This study provides an overview of the collaboration formation process in the insurance governance design of Indonesian Labor which is based on observation and in-depth interview in the institutional actors in the institutional environments. The actors in this neighborhood consist of a government, an insurance consortium, and Indonesian Labor. The player interaction relationship describes the complexity of players relationships. Their involvement becomes multi-stakeholders in insurance service of Indonesian Labor, which aims to serve Indonesian Labor. The management of this service is provided in an insurance consortium of Indonesian Labor. Government acts as regulator and facilitators. Indonesian Labor serves as the subject of the service. These actors interact and the interaction contains particular construction, provides a specific pattern, works in the player interest and there is a dependence focusing on changes and the possibility of forming new governance design. This study was explored, with the approach of institutional theory, principalagent theory, and its problems.

Institutional design to the insurance scheme implementation of Indonesian Labor inside shows the governance by involving the role, the power, and authority through delegation. This fact happens because the government is often unable to conduct themselves in regulation (Ljungholm, 2014). In the implementation of the law, it also needs information, cost, and resources so that it needs partnerships and private sector (Minkoff, 2013). The consequence of this relationship is the provision of power and authority to the partners (private) to jointly provide services because private sector involvement in service is caused by their budgetary reasons and seeks service innovation through the relationship (Roehrich, Lewis, \& George, 2014). This delegation can also be regarded as an important tool to attract resource development (Medda, Carbonaro, \& Davis, 2013) when there are a lot of resource developments. Then, it will provide 
benefits that lead to efficiency (Otčenášková, Kolerová, \& Bureš, 2014), and will bring resources incorporation consequences used to serve the community (Zhang \& Chen, 2013). The actual purpose of delegation as one form of innovation in the search for solutions (Felin \& Zenger, 2014) used in the public service infrastructure aimed at distributing public support in various sectors (Brinkerhoff \& Brinkerhoff, 2011). Thus, Indonesian Labor and the government as actors who have given their authority to the insurance consortium (an agent) reverse the right to obtain an advantage of that relationship and as a result, Indonesian Labor receives services as needed.

Institutional relations show a certain formal interaction, in which the actors coordinate and participate in different realms although the insurance consortium should be government's arm. Thus, the insurance consortium acts as an agent entrusted to manage public goods/services. However, this relationship was born in different environments at various authorities so that it will have different interests. Those differences may create conflicts, and the conflicts will diminish the effectiveness of the policy (Elias \& Alkadry, 2011). Thus, the accuracy of the mechanism selection is necessary for the success of the procedure. Institutional mechanism selection depends on the institutional environment (related to property rights, contracts, credibility, judicial, norms, customs, etc.) that can cause changes in comparative of costs, hierarchical relationships and the hybrid organization (corporate and bureaucratic) (Sykuta \& Cook, 2001). Institutional environment is related to the rule of playing in community and environment that regulate community interactions. If the public blunder exists in using the authority relating to the environment without regarding ethics and norms, it will indicate the lack of supervision control and rule of playing in a social service (Greer, 2010).

Governance mechanisms can be a pattern of collaboration, cooperation, interaction, and contractual relationship/negotiations. Relational and contractual mechanisms is a complete form of private and administration governance (Roehrich et al., 2014). The mechanism includes the factors related to management depending on each characteristic (Abdi \& Aulakh, 2014). Then, authorization is conducted through the provision of institutional infrastructure, and it becomes the main feature of the private-government partnership (Engel, Fischer, \& Galetovic, 2013). Absolutely, in any insurance management mechanism of Indonesian Labor also includes interaction, collaboration or even negotiations, given that there is a division of roles and responsibilities in implementation, then each party who plays a role should participate each other to create change in the service system. It means that there are actions to promote the interests of partnership members, which should not be mutual "hands off" when there are problems in practice. Thus, institutional governance mechanism describes how the role of each actor working in the arrangements that have been agreed, of course, featured mechanism ideally, i.e. each actor plays a role in the mechanism of action and competes to be the best (Balasubramanian \& George, 2012).

Meanwhile, the insurance management of migrant labors in Brazil, Russia, India, and China, as the research results by Pieters \& Schoukens (2012), the administration in these four countries is managed by the private sector with a fewer portion, and the government with more portions (Pieters \& Schoukens, 2012). This management is accomplished by the government and private sector with different power parts/not entirely given to the private company. Brazil and India provide its management with private companies, but in its development, China and Russia provide the management of social insurance of migrant labor entirely on the government. This study result also suggests that the social insurance of migrant labor in Brazil, Russia, India and China also provides coordination problems and the simplification of the service structure. However, Russia and China, slowly undergo performance improvement processes on social insurance since managed entirely by the government. By the experience of the management of some countries have been giving lessons on the management mechanism election and appropriate institutional design. Thus, the social insurance institutional design of Indonesian Labor has the challenge to improve in better direction and actors improved behavior involved. If the institutional design options are harmful principally, then the principal will lose the ability to influence the decision framework to be made (Kaskarelis, 2010), so it requires an administrator to improve through increasing competitive skills to resolve the problem in a professional manner (Benner \& Pastor, 2015).

\section{Method}

A phenomenology approach was the proper way for case analysis. The data is logged from observation and in-depth interviews with core actors associated with the research, the representatives of the Government, representatives of the insurance consortium and representatives of Indonesian Labor. The player is distinguished as authorized agents and the authority, i.e. the government (providing insurance management authority of Indonesian Labor), and Indonesian Labor as the authorizer over insurance premium management paid, Consortium insurance as an actor on receiving authority over insurance management of Indonesian Labor and decision makers. This study begins with preliminary research conducted in 2013, includes the observation and related study to the institutional framework covering insurance governance of Indonesian Labor, within the region for the management of Indonesian Labor in East Java, Indonesia. 


\section{Finding and Discussion}

The institutional design illustrates the insurance governance mechanism pattern of Indonesian Labor contains authority structure. This pattern is filled with an imbalance of authority that focuses on and by the interests of each actor involved. The authority relationship between the principal (the endorser: government and Indonesian Labor) and agent cause dependency between the parties. Born from dependence and structure, this authority is identical with the ability of the actors in playing a role that is an imbalance with the player who is played by the other party. The occurrence of the pattern of dependence is due to the imbalance of bargaining power of each player in taking decisions and in using the authority they own (principal and agent).

There are two types of elements contained in the institutional relationship in the management of insurance of this Indonesian Labor, i.e. the principal and agent. Principal and agent are the perpetrator/actor who has authority and interest to them, so that, there are authority and interest in the relationship between principal and agent. Thus, when the actor masters all sources that are interesting and profitable for him, then he will execute his authority in a way to meet those profits. The attempt to exercise authority is exercised through certain transactions and realized through an agreement.

As well as on Indonesian Labor as principal that gives authority over premiums paid to the insurance consortium to manage the premium cost and entitled to receive what they are entitled according to his interests. Government as the principal who plays a role and gives authority to the insurance consortium to manage insurance of Indonesian Labor as protection services. Insurance Consortium, as the agent, acts as the parties who have the power and authority to manage insurance of Indonesian Labor also have the power and interests partnered with placement delivery company of private Indonesian Labor. Thus, this institutional design is run by the principal and actor of the agent, and the agent already has a partner in the management of an insurance of Indonesian Labor.

\subsection{Government Dependence on Insurance Consortium}

Governments as regulators have limited decision making, like a vast and mighty restrictions that prevent to play a role in some ways. Like, the difference of working area, the existing power and the limitations of government do not have the effort if there is a problem. Limited resources and asset management limit the authority. Limitations of the government's authority in overseeing the work of insurance consortium (agent) are indicated by claiming a right to the limited management of resources and assets. Likewise, in an insurance consortium as an agent arguing that the right to adequately manage resources and assets is an insurance consortium. This is consistent with the statement of insurance consortium representative, as follows:

"Our party has an advantage in the management of insurance, because according to the law and the Minister Regulation, that the insurance consortium of Indonesian Labor is given full authority to manage insurance of Indonesian Labor, so we have the advantage of resources, especially the completeness of the data we have" (agent representative)

Thus, based on management rights by the consortium entirely, it can be said that if someone claims to have right to perform particular action, but the other party does not recognize the rights (for its limit), then he has no right to take any decision relating thereto. If the government as the principal does not have an interest in the consequences of resource and asset management most widely owned by an insurance consortium, it is possible that the government as a principal to impose to have authority in using resources and assets, yet limited. It is a moral obligation that the government also has the right to know about resource and asset management of insurance management of Indonesian Labor and can be performed through informal decision-making.

Therefore, the decision on resource and asset management of Indonesian Labor protection, by Law No. 39 of 2004 also states that those who manage Indonesian Labor insurance is the insurance consortium of Indonesian Labor. Limitations of decision-making describe the high authority. This authority has the right to decide, direct others to take action or perform tasks regarding achieving objectives (Preameaux, in Stainland, 2003). Thus, the authority that occurs between the division of government role, and also related to the insurance management of Indonesian Labor in the insurance consortium may mean there is a classification of individual actors regarding using rights (decision-making). Thus, the authority has an impact on the need for coordination, communication, and surveillance. It is intended to realize the integration of interaction in achieving a common goal, because according to Jones (in Stainland, 2003) that the combination of communication as the process of coordinating the implementation of the tasks, functions of division role and labor department for the achievement of common goals. 


\subsection{Dependence of Indonesian Labor in Insurance Consortium}

Provision of insurance management facilities received by the insurance consortium causes everything performed by actors with the purpose to improve the realization of the interests of each actor, and it depends on the power and authority they have. The authority of government as principal depicts the power of resources on their interests and in which under their control, in order to meet its interests based on provisions of the Act and other regulations. However, on the other hand, the insurance consortium has greater authority, in which the decision is likely to be able to take control over resources and asset of insurance management of Indonesian Labor and for this, he is powerful and has an interest. The process of resource and asset management of Indonesian Labor coverage will be based on the power and interests of each actor. The process will follow the entire purpose of each actor's interests. It is assumed that the insurance consortium will enable him to realize any benefit he has for resources and assets under his control. So as in Indonesian Labor, the magnitude of its dependence on the role of the consortium causes no other choice not to take the insurance as the obligation to practice the law commands. Thus, the decision-making authority is entirely in the agent (an insurance consortium). The consortium with its partners (companies of private Indonesian Labor placement) concerned to manage Indonesian Labor insurance, although this agency partner is interested only in providing information to Indonesian Labor and register Indonesian Labor to the insurance consortium, but rather the power of this information has a particular interest. As a result, Indonesian Labor as the principal does not have effort in decision-making authority by Indonesian Labor insurance. It makes Indonesian Labor dependence on consortium because Indonesian Labor admits that their participation in insurance is a liability. As conveyed by representatives of Indonesian Labor as follows:

"Insurance is compulsory, so registering to the consortium is compulsory, then there is no other option but joining a particular consortium" (representative of Indonesian Labor)

3.3 Indonesian Labor Dependence on the Private Indonesian Labor Placement Delivery Company (Agent Partner, but on the Independent Indonesian Labor)

TKI dependence on agent partners at the time of registration of insurance brings consequence that Indonesian Labor has no control over important events/incidences, even Indonesian Labor will be losing power over the right to take decisions by their interests. This condition will make Indonesian Labor has only a partial power, meaning that there is another important part of benefits that is not able to do it by itself, it is highly dependent on the agent partner, even there is an authority in decision making. This is consistent with the statement of representatives of Indonesian Labor as follows:

"I take insurance, but it is the Company who enrolls, I do not understand anything, I just know it must be well, I have no any choice, they say it is compulsory, so it depends on what the Company says, I really do not understand anything, I even do not know how form is, everything is decided by the Company, I could not have any idea, I do not understand anything, then how" (representative of Indonesian Labor)

The statement hints that he has no power over decision-making related to Indonesian Labor insurance, for which he should have full authority over decision-making because it is associated with himself, especially its insurance contracts will apply between himself and the insurance consortium. However, Indonesian Labor gives the right to control its decision to the partners, so it is in the partners' hands to manage the information. The authority of its decision is also in the partners' hands, not in the Indonesian Labor's. Although in reality, the decision-making to register for this insurance is only when enrolling, meaning that the Indonesian Labor only gives power over the decision to choose a consortium when enrolling, do not give full authority over all information and power inherent in the process of registering. It can be observed that Indonesian Labor has been "handed over the right to control," even "deliver the power" to PPTKIS to all events and decisions related to the process of registering insurance. Unless Indonesian Labor independently registers.

In fact, there is compulsion in the process of "delivering control" entirely. This fact occurs because Indonesian Labor has no other choice and does not have money to pay for such insurance so that PPTKIS previously imposes the matter of the insurance registration and those related with the process, Indonesian Labor will be paid with debt to a salary cut.

Compulsion experienced by Indonesian Labor has an impact that agent partners have full authority over the Indonesian Labor's decision on the workers who should have been not only delivering the power entirely in the process, but it is the right to control the action for which being delivered. This phenomenon becomes an opportunity for agent partners to master the right to choose for Indonesian Labor. Indonesian Labor will also lose their right to control their every action while enrolling for insurance because they have no chance to sort out the insurance consortium which he 
would choose. The Indonesian Labor placement delivery party who acts as agent partners holds the rights adequately, so that the labors can no longer disagree (Indonesian Labor automatically agrees/must agree), and if they agree, then such right is fully controlled by agent partner. Thus, Indonesian Labor has no control over other resources, even giving ideas/suggestions or relevant opinions related to Indonesian Labor insurance. Indonesian Labor is never present in the process of "choose" and "decide" which is associated with Indonesian Labor insurance, even when they participate in the recruitment program by the government. However, although it can be said that Indonesian Labor does not have the opportunity to choose and make decisions, but they still have the right to hold the right to have insurance membership card (to keep it by himself). It means that right to have insurance cards is still owned by Indonesian Labor, even though they don't have the right to take a decision.

Granting authority to the Indonesian Labor placement delivery party (agent partner) by Indonesian Labor begins when registering to be prospective Indonesian Labor. Not only occur while registering the insurance, but the right to choose and the power of Indonesian Labor is also never presented by agent partner. It is clear that when a prospective labor comes to an agency partner, then he gives all powers indirectly to the agency partner. Thus, Indonesian Labor has chance and authority to the agency partner to control all actions that should be authorized by Indonesian Labor, means that the agent partner has to treat the right to control the Indonesian Labor's actions as a resource, although it is the labors make all costs during the process to be Indonesian Labor. The transfer of the control right over the decisions and actions taken by Indonesian Labor to the agent partner is carried by compulsion and inability to make decisions.

Indonesian Labor cannot control his power right when registering and choosing a consortium of Indonesian Labor, and voluntarily gives their proxies to agent partners, and in addition, Indonesian Labor does hold the right to transfer its rights to agency partners. It is assumed that if Indonesian Labor is authorized, they get control of the power given to agency partner, as well as the rights that have been granted, then a power of attorney is granted only for the purpose of convenience. However, the power given cannot be controlled by Indonesian Labor because of the limited information and the ability or power to make his decisions.

Indonesian Labor is given the opportunity by Act or any other rule to independently choose the insurance consortium and enroll himself in Indonesian Labor insurance; it can mean that not all powers can be given freely to others. Given the number of Indonesian Labor migrating through agent partner or government shows that they are not forced to have power in choosing insurance consortium of Indonesian Labor. Granting this right regards to the right to manage the actions of the power that have been given to the other party. If Indonesian Labor automatically registers himself (without going through another party), then it is very different from what they would be. It is because the labor has no control over the actions of insurance consortium at the time of insurance agreement execution (in this case, there is no external compensation). It means that Indonesian Labor has no costs borne and can rebroadcast information, although they still have to pay the premium with their money.

The labors who authorize power to agent partners have no authority to choose or act as their personal wishes, so there is a mutual relationship in which the employees assume that the decision is considered equal to what has been decided by the agent partner. It is justified according to early report (Alchian \& Demsetz, 1972) that the party has delegated power to another party, then they will no longer have the decision-making authority, but it does not contain all the risks associated with the authority of the decision. This fact also happens in prospective labor/the workers, with the risks inherent in the decision of agent partners that will automatically be borne by the potential labor/employees. However, in contrast to Jensen (in Linder \& Nicolai, 2013) that the delegation of the decision to the other party has an impact on the interests of the authorizer. Thus, although prospective labor/workers are powerless to make a decision and give it to the agent partner, the agency partner should take decisions in the interest of prospective labor/employees despite the risks inherent in the decision will be in the potential labor/labors. At least, if it already takes decisions on behalf of the interests of prospective labor/labors, the risk attached to such decisions will shrink along with the magnitude of the interests of potential labor/labors who are with the decision.

\subsection{Dependence of Insurance Consortium to the Partner (Indonesian Labor Placement Delivery Party)}

Because all Indonesian Labor's decision-making control right is submitted to Indonesian Labor placement delivery party related to insurance and insurance consortium, then this distribution side as an insurance consortium partners (agents) are very useful to the survival of the "profit" of insurance consortium. A wide variety of conditions and circumstances surrounding the incident, still have usefulness/advantage, even if it is only perceived by others (agent partners). Thus, it is very naturally digestible that one (a group), which holds the rights to another person (other groups) can give you the good to the other person (if Indonesian Labor feels disadvantaged) and the relevant parties involved (the other party) which is an insurance consortium of Indonesian Labor. 
A delegation of tasks may be beneficial because of the reduced time or other advantages in the execution of certain tasks (Laffon \& Martimort, 2001), like Indonesian Labor who feel benefited if giving rights to the Indonesian Labor placement delivery party, because the labor finds it easy to take care of the insurance. It is like following Indonesian Labor representative statement:

"it is so good when taken care of, well, it should become debt, but it could be paid up later" (representative of Indonesian Labor)

As evidenced by the fact, Indonesian Labor gives their right to the Indonesian Labor placement delivery party, and they can accept it, then there is a reward in which they would go through later in return for the obligation to replace all they have received. Thus, the transfer of rights to be a resource that has value and the right to be part of it. Sources of this value will also be an advantage for the insurance consortium of Indonesian Labor because they will gain a lot of conveniences if they go through the placement delivery party. Thus, the services of this agent to the insurance consortium of Indonesian Labor starts from the Indonesian Labor's delivery of power to its partners on the insurance management of Indonesian Labor. This is consistent with the statement of government representatives as follows:

"agent partners are very useful for the continuity of the insurance consortium of Indonesian Labor because without their services, the actual partner is their consumers, then the consortium will be struggling to find customers, and, by the existence of this partner, they will just stay waiting for customers, just need to keep a good relationship"

Then, it is stated by Indonesian Labor insurance consortium representative as follows:

"our partner was instrumental in the continuity of advantage of our company, as the Indonesian Labor delivery/placement company in which from the beginning, in the process of our insurance services, they are the one who determines the number of customers, and insurance documents we manage of"

The private Indonesian Labor placement delivery company becomes the suitable partner to the business continuity of Indonesian Labor insurance consortium. Thus, the existence of a transfer of rights that have been submitted by the Indonesian Labor to Indonesian Labor placement company determines where the power is; the company uses its power to choose an insurance/insurance consortium company he will want for the prospective labor. The power may be limited by the existence of other rights, i.e. the Indonesian Labor insurance consortium rights to manage resources and assets associated with Indonesian Labor protection, and the right is only at the election of registration. The relationship between the private Indonesian Labor placement delivery company (agent partner) and an insurance consortium (agents) is mutually beneficial, although the relationship is to eliminate the labor's power right to take a decision.

The mutually beneficial relationship between the agency and its partners will be running uninterruptedly if the parties who indirectly rely on each other have mutually trust. The link also indicates that both can control the action, specifically agent partners have the power because they have a chance to choose. Insurance Consortium only depends on the decision of choosing partners that should belong to wholly-owned by prospective labors. Control right which has greater power in agent partner's hands, because they have the ability to do or make decisions. Thus, it can be said that the power given by Indonesian Labor to the private Indonesian Labor placement delivery company is voluntary because of the compulsion. The forced power provided by Indonesian Labor also makes the pattern of dependence on the insurance consortium, always to establish a good relationship with its partners to create a profit and business continuity.

\subsection{Dependence of Indonesian Labor to the Government}

Weaknesses that can be found from the dependence of the actor is associated with the power relationship, especially between Indonesian Labor and the private Indonesian Labor placement delivery company. Sources of weakness are to the right which is fully granted to the Company by the labor, so it cannot control their actions, and to some extent, as a consequence, Indonesian Labor is under the control of a private company as a result of a transaction of the power. This relationship often leads to Indonesian Labor loses control over the powers that have been granted to the private Indonesian Labor placement delivery company. Ultimately, it can trigger a greater control relationship. The company is entitled to do anything to Indonesian Labor in which only based on particular interests (profit for the private Indonesian Labor placement delivery company).

The condition leads to the consequence of Indonesian Labor dependence on the government. Indonesian Labor always tries to find comfort on all issues through the government. Although they give all insurance powers to private Indonesian Labor placement delivery company. However, regarding the issue that shackles them, only the government who will be responsible. As expressed by the representative of Indonesian Labor as follows: 
"All concerns to the government, not to others, as I know the best place and open is the government, there is a specific complaint, who else could be reached if not the government."

Indonesian Labor dependence on the government occurs because they think that the government is capable of resolving the problems they face. Although power control owned by the labor and the management as a principal confirms that explicitly for the implementation of Indonesian Labor insurance is require of insurance consortium actor dependence as an agent.

Act No. 39 of 2004 and Manpower and Transmigration Minister Rule No. 7 of 2010 and its amendment No. 1 of 2012 have set various institutional authorities concerned with Indonesian Labor insurance scheme, and in the Act, it has been mentioned that the insurance is related to the protection of Indonesian Labor. Full implementation is in insurance consortium's hands, and the role of the private Indonesian Labor placement delivery company dominates on Indonesian Labor, then the actualization of justice in acting by Act No. 39 of 2004 have not materialized well.

Thus, the concept of protection outlined in Act No. 39 of 2004 has made the foundation of institutional works according to their respective proxies. At the same time, the law opened by a specific conflict opportunities over the division of power is not balanced and fair. Dependency relationship between existing actors shows how many possibilities for the creation of a dispute between these actors. This conflict is discussed in Dwijowijoto (2012) that the conflict is seen as a fact that occurred in an ordinary life which is understood as a competition for resources due to the scarcity.

Conflicts that arise, especially for prospective labor/workers in viewing the private Indonesian Labor placement delivery company as the instrumental party but the accountability is questioned. For the government as the party who is responsible for the protection to Indonesian Labor. Indeed, some existing problems are raised because of massive dependencies between actors, and in the end, some these issues "remains hanging," because of the powerlessness of the principal to the agent. In this case, in particular on the functions of government as "affair center" for labors, which should be a concern and authority of government.

Meanwhile, the government "allow" themselves to be controlled by the consortium (agent) still in the powerlessness of authority with all obligation demands that must be completed. As for labor, everything is controlled by an agency partner, still in financial powerlessness but also inherent an obligation to participate in Indonesian Labor insurance along with other complementary obligations. It will be a complicated conflict. Given that, the conflict will be more complicated, if the actor is too convinced on powerlessness associated with the resources (decision) (Dwijowijoto, 2012). It means that the conflict will occur, not only a matter of interest but the scarcity of resources and the value of the interaction between actors. The success of the interaction between actors is pretty much determined by their capacity "to bear the conflict" and proficiency in "parsing" the conflict because inevitably they've created destiny with the conflict. However, these interdependent actors realize that the conflict which is dominated by power will be detrimental to them (weak capacity). Even though, all interactions walk in the corridors of the policy set out in the Act or other formal rules.

If this insurance scheme is agreed upon the management format as reflected in the Act No. 39 of 2004 and Manpower and Transmigration Minister Rule No. 7 of 2010 and its amendment No. 1 of 2012; the next question is: can the laws and regulations guarantee the institutional independence sovereignty of each actor fully?, There is only a prerequisite of Law implementation and it is filled with traps due to the interaction of agent principals and agents with agency partners or even the principal with agent partner. In the end, the traps have the potential to create existing conflicts and rules which are very binding/dependent between actors, especially the government and the insurance consortium. Meanwhile, the dispute interaction relationship between Indonesian Labor and private Indonesian Labor placement delivery company is due to the helplessness of Indonesian Labor to the finance and decision-making.

Based on these realities, the policy achievement between conflicts can be resolved if there is a high level of success or mitigate the risk or small failure (although there is a conflict), i.e. through the cost approach, profit sharing, or share the risk (Dwijowijoto, 2012). The justification of Nugroho's opinion can be said indirectly that the purpose of policy would still be achieved and succeed, although the strategic direction will be determined based on the many possibilities accepted by all actors. It means that the government and Indonesian Labor as principal can spend some other money (costs) as a consequence of the conflict caused by the helplessness of resources (financial for Indonesian Labor, and information for the government), or there is a clear benefit sharing between actors. So the success of Indonesian Labor insurance policy as the implementation of social security for the labor is largely determined by the design of the deal, although in the design application, there will be conflicts between actors.

\subsection{Institutional Design}

Based on the description of the identification of the actor dependency that has been described previously, this 
dependency forms specific power pattern. The power that illustrates that Act No. 39 of 2004 provides trap over control of certain actors in Indonesian Labor insurance management. In the description of the identification previously, it is found that the insurance consortium as a powerful actor for its full authority and the agent partner has full power over the information they have. Meanwhile, the government has limitations in information resources and authority that resulted in the decision-making, as well as prospective labor/labors who are helpless to give powerfully to private Indonesian Labor placement delivery company on the use of their voting rights and other related things. Indonesian Labor has the right to individually select the consortium by his choice, but because it will also have limitations and inability, they remain on the powerless party, even though in reality, the relationship of cooperation regarding Indonesian Labor insurance is very individualized.

Thus, the institutional design depicted in matters of governance mechanisms identified shows the dependency issue between actors. This issue brings the consequence that the institutional design formed is fulfilled by the unbalanced pattern of power, that insurance consortium agent and its partners have the ability to put pressure on Indonesian Labor and the government, as a result of their helplessness. The power center is located on the agent (an insurance consortium) and private Indonesian Labor placement delivery company from the mouth of authority for labors. (Private company is also a consortium partner). Overview of power has an impact on the rationality of the decisions made by each actor. Since each player will continue to act in their interests, to maximize their separate utility (Holmstrom \& Milgrom, 1991). Meanwhile, Indonesian Labor and the government cannot increase the power position due to Act №. 39 of 2004, and other Regulations have placed it, so we need an agreement to be balanced/beneficial for many stakeholders.

Governance mechanisms in its designs are colored with the dominant power structure. It means that the power that color pattern of agreement demonstrates the capacity of individual actors to achieve a deal. However, the purpose of the agreement to provide protection for labors has not been fully achieved, since the agreement is still dominated by the power of individual actors, even the actors (an insurance consortium) to be a certain player on the decision of the deal. In fact, this actor is only as an agent of power (premiums) paid by the labor and power of management provided by the government. This power is used to influence or change any decision on a deal. Also, the achievement of the objectives, inside the power, there are persuasion and compulsion. The reality, this power has weakened the position of Indonesian Labor and the government (as the principal) in the decision-making. In the deal, it raises many implications (costs and usefulness) that are also not for the principal. The greater the power of the actor, the more profits earned (Caporaso \& Levine, 1992). In this design, the power can be construed as ownership and control over other important decisions on other actors as well as determining the success of the labor protection policy.

Various dynamics that occur in institutional design is a natural and normal part of the implementation of granting authority to another party. Nevertheless, the matter is the application of the insurance management is not only a part of the power of individual actors but also there is another important part, i.e. the application of a form of protection to the labor who insists on services based on the fulfillment of rights/guarantees for Indonesian Labor on safety, health and fulfillment of guarantee on the welfare of workers. Then there are the protection missions and serve in the interactions. Not strengthening the authority of power and a tendency to weaken the power over other actors. Then, the governance mechanisms identified from the patterns of the power structure between actors who implement this deal includes dimensions of reality, i.e. the ability of the players to achieve adaptation value in their respective roles. The roles contain idealistic aspects, that is the quality of laws and other formal regulations as the support of forming power (given formal rules), and the quality of an informal agreement that is "present" in the official rules. Then, finally, it contains the dimensions of flexibility: the actor's ability to influence and adjust to the "presence" of other actors and able to present the agreement as mutually beneficial efforts, share risks and useful between actors.

By understanding these dimensions, the dynamic of the issues that are present regularly interact to form a particular institutional design in the process of interaction, thus reflecting the strength in the interests of individual actors. Similarly, it is understood that the process also reflects the institutional design changing needs that illustrate the need for an actor maturity in managing the power that he has, and ultimately impacted on the Indonesian Labor insurance service management produced.

\section{Conclusion and Further Study}

Agreement governance mechanism contains many patterns of power. Positions of power show the dependence between actors. This causes the principal as the authority and does not necessarily have the highest power, and the agent as a party whose given the authority to manage insurance also has powers beyond the authority granted by the principal. Agency relationships related to Indonesian Labor insurance shows the findings that the labor as principal no longer has a choice in the decision-making unless the labor independently registers their insurance to insurance consortium. 
If Indonesian Labor "choose" to give power to the private Indonesian Labor placement delivery company, indirectly, Indonesian Labor has transferred decision authority to the private Indonesian Labor placement delivery company. It happens because of compulsion on the powerlessness of resource ownership (financial). So is the government's position as a principal. The government does not have the ability to control the consortium actions and some measures to protect the labor. This occurs because of the lack of resources (information) and asset management, so it limits the authority. Mastery of assets such as facilities, particularly all information is not enough to make the government has high bargaining power. Some other things that make low bargaining power is caused by Act No. 39 of 2004 and other formal regulations are also the position in such conditions.

The high dependence of Indonesian Labor and the government to the consortium and full authority of consortium over the management of the insurance brings the consequence that the institutional design includes attitudes, decisions, and actions of Indonesian Labor and the government as a principal depends on the attitudes, decisions and actions of the insurance consortium. In the process, there is a horizontal conflict, the conflict between the insurance consortiums. Conflict is triggered due to competitive reasons and would "appear" to perform well in the eyes of the government.

Thus, the conclusion shows that the institutional design which consists unbalanced power pattern, as a result of the actor's dependence in certain mechanism. Thus, the analysis approach used is a phenomenological method, then to find the ideal design of governance and mechanisms, it needs other, more innovative approaches. For example, further study with a comparative analysis approach. It needs a comparative review of the institutional design of Indonesian Labor insurance institutions in other countries in comparison to the ideal of institutional design. As well as the limitations in this study only look at the issue of the mechanism from problem dynamic of actor's dependency, then it is suggested to do further research to conduct studies with other problems to reveal/explore other issues in Indonesian Labor Insurance institutional design.

\section{References}

Abdi, M., \& Aulakh, P. S. (2014). Locus of Uncertainty and the Relationship Between Contractual and Relational Governance in CrossBorder Interfirm Relationships. Journal of Management, XX(X), 1-33. http://doi.org/10.1177/0149206314541152

Alchian, A. A., \& Demsetz, H. (1972). Production, information costs, and economic organization. The American Economic Review, 62(5), $777-795$.

Balasubramanian, N., \& George, R. (2012). Corporate governance and the Indian institutional context: Emerging mechanisms and challenges. IIMB Management Review, 24(4), 215-233. http://doi.org/10.1016/j.imb.2012.10.001

Benner, C., \& Pastor, M. (2015). Collaboration, Conflict, and Community Building at the Regional Scale: Implications for Advocacy Planning. Journal of Planning Education and Research, 35(3), 307-322. http://doi.org/10.1177/0739456X15580024

Brinkerhoff, D. W., \& Brinkerhoff, J. M. (2011). Public-private partnerships: Perspectives on purposes, publicness, and good governance. Public Administration and Development, 31(1), 2-14. http://doi.org/10.1002/pad.584

Caporaso, J. A., \& Levine, D. P. (1992). Theories of political economics. New York: Cambridge University Press.

Dwijowijoto, N. R. (2012). Public Policy (Dinamika Kebijakan.Analisis Kebijakan. Manajemen Kebijakan). Jakarta: PT. Alex Media Komputindo.

Elias, M. V., \& Alkadry, M. G. (2011). Constructive Conflict, Participation, and Shared Governance. Administration \& Society, 43(8), 869895. http://doi.org/10.1177/0095399711422495

Engel, E., Fischer, R., \& Galetovic, A. (2013). The basic public finance of public-private partnership. Journal of the European Economic Association, 11(1), 83-111. http://doi.org/10.1111/j.1542-4774.2012.01105.x

Felin, T., \& Zenger, T. R. (2014). Closed or open innovation? Problem solving and the governance choice. Research Policy, 43(5), 914925. http://doi.org/10.1016/j.respol.2013.09.006

Greer, S. L. (2010). How Does Decentralisation Affect the Welfare State? Territorial Politics and the Welfare State in the UK and US. Journal of Social Policy, 39(2), 181. http://doi.org/10.1017/S0047279409990407

Holmstrom, B., \& Milgrom, P. (1991). Multitask Principal-Agent Analyses: Incentive Contracts, Asset Ownership, and Job Design. Journal of Law, Economics, and Organization, 7(special), 24-52. http://doi.org/10.1093/jleo/7.special_issue.24

Ljungholm, D. P. (2014). Preventing Illegal Migration in Romania. Procedia - Social and Behavioral Sciences, 149, 741-745. http://doi.org/10.1016/j.sbspro.2014.08.302

Medda, F. R., Carbonaro, G., \& Davis, S. L. (2013). Public private partnerships in transportation: Some insights from the European experience. IATSS Research, 36(2), 83-87. http://doi.org/10.1016/j.iatssr.2012.11.002

Minkoff, S. L. (2013). From Competition to Cooperation: A Dyadic Approach to Interlocal Developmental Agreements. American Politics Research, 41(2), 261-297. http://doi.org/10.1177/1532673X12451310

Otčenášková, T., Kolerová, K., \& Bureš, V. (2014). Sharing of Resources: Theoretical Background and a Case Study. Procedia - Social and Behavioral Sciences, 109, 698-705. http://doi.org/10.1016/j.sbspro.2013.12.532

Pieters, D., \& Schoukens, P. (2012). Social Security in the BRIC Countries: Brazil, Russia, India and China. Compensation \& Benefits Review, 44(3), 154-164. http://doi.org/10.1177/0886368712455608

Roehrich, J. K., Lewis, M. A., \& George, G. (2014). Are public-private partnerships a healthy option? A systematic literature review. 
Social Science \& Medicine, 113, 110-119. http://doi.org/10.1016/j.socscimed.2014.03.037

Sykuta, M., \& Cook, M. L. (2001). A New Institutional Economics Approach to Contracts and Cooperatives. American Journal of Agricultural Economics, 83(5), 1-19.

Zhang, X., \& Chen, S. (2013). A systematic framework for infrastructure development through public private partnerships. IATSS Research, 36(2), 88-97. http://doi.org/10.1016/j.iatssr.2012.11.001 